\title{
高抵抗全面導電釉懸垂がいしの開発
}

$\begin{array}{llllll}\text { 正 } & \text { 篠田 } & \text { 明秀* } & \text { 正 員 知屋城清信* } \\ \text { 正 員 岡田 } & \text { 英幸* } & \text { 正 員 鈴木 } & \text { 良博** } \\ \text { 正員 伊藤 } & \text { 進 }^{* *} & \text { 終身会員 内藤 } & \text { 克彦*** }\end{array}$

\section{Development and Performance Verification of High Resistance Semiconducting} Glaze Insulators

Akihide Shinoda*, Member, Kiyonobu Chiyajo*, Member, Hideyuki Okada*, Member, Yoshihiro Suzuki**, Member, Susumu Ito**, Member, Katsuhiko Naito ${ }^{* * *}$, Life Member

In case of transmission lines along the sea coast, audible noise due to partial discharges may occur from insulators when contaminated with sea salt and wetted. From the consideration to residents, insulator washing has been performed periodically, but this results in increase in the maintenance cost. As a countermeasure to reduce the audible noise, semiconducting glaze insulator (DC resistance approx. $20 \mathrm{M} \Omega$ ) has been developed and used. However, in case of a very special environment with direct spraying of sea water in seaside districts, there seems to be some risk of thermal runaway because voltage concentration on very small number of insulator units in a string is possible and it may rise the temperature of those units up to the critical point.

In this paper, the thermal runaway mechanism is clarified from view point of input and output energy of the semiconducting glaze insulator under contaminated and wetted condition. The surface temperature starting thermal runaway is estimated from various experiments. As a result, the high resistance semiconducting glaze insulator, which has higher thermal runaway withstand capacity and acceptable agreeable audible noise characteristics is developed and subjected to the field evaluation.

キーワード：導電釉，高抵抗導電釉，熱逸走，がいし，污損，部分放電音，部分放電

Keywords: semiconducting glaze, high resistance, thermal runaway, insulator, contamination, audible noise, partial discharge

\section{1. まえがき}

臨海部を経過する送電線路では , 海塩粒子によりがいし 表面が污損・湿潤し，これにより部分放電音が発生する場 合がある。部分放電音が発生しても設備上の問題および人 体への危険性はないものの，地域住民の生活環境に対する 配慮から定期的ながいし洗浄を実施しており，これが保守 費用の増大につながっている。

\footnotetext{
*中部電力 (株)

T 461-8680 名古屋市東区東新町 1

Chubu Electric Power Co. Inc.

1, Higashi-shincho, Higashi-ku, Nagoya 461-8680

** 日本ガイシ (株)

₹ 485-8566 小牧市二重堀田神 1155

NGK Insulators, Ltd.

1155, Tagami, Futaebori, Komaki 485-8566

*** 名城大学

干 468-8502 名古屋市天白区塩釜口 1-501

Meijyo University

1-501, Shiogamaguchi, Tenpaku-ku, Nagoya 468-8502
}

この部分放電音抑制技術のひとつにがし表面に半導電 性釉薬 (以下導電釉という) を施し, 直流抵抗を $20 \mathrm{M} \Omega$ 程 度とした全面導電釉懸垂がいし（以下従来タイプ導電釉が いしという）があるが, がいしの熱逸走を防ぐために使用

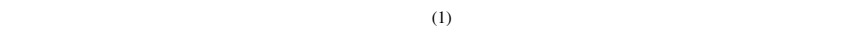
音の発生か懸念される海水の飛沫に曝されるような污損環 境下では, がいし連中の電圧分担のアンバランス等による 少数がいしへの電圧集中による熱逸走が問題とされ，適用 されてこなかった。

本報告は，上記のような污損湿潤環境下に適用可能な高 抵抗全面導電釉懸垂がいし（以下高抵抗導電釉がいしとい う）を製作し，実用性能を検証した結果を取りまとめたも のである。

\section{2. 導電婇がいしの材料および構造}

導電釉がいしは, 通常の釉薬材料中に導電性金属酸化物 $\left(\mathrm{SnO}_{2}, \mathrm{Sb}_{2} \mathrm{O}_{3}\right.$ 等) を加えた導電釉を磁器部全面に施し, セ メントを介して金具と導電釉との導通をとるため, 通常ぺ 


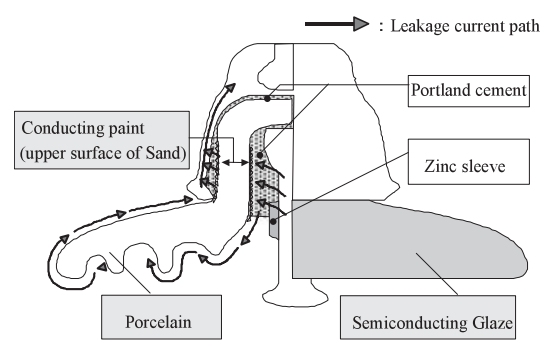

図 1 導電釉がいしの材料および構造

Fig. 1. Material and construction of semiconducting glaze insulator.

イントにカーボンを添加した導電ペイントを用いた図 1 の ような構造をしている。これ以外の構成材料や笠部形状等 の構造は，すべて通常釉がいしと同じであり，臨海部の過 酷な海塩污損環境下での使用を考慮して，ピン部の電食対 策に亜鉛スリーブの採用を基本としている。導電釉がいし は, 通常釉がいしの材料および構造を保つことで, 従来か らの設計思想や各種試験，使用害績等を継承しつつ，一方， 前述のような半導電性を有する材料および構造を用いるこ とで, 漏れ電流ががいし沿面を流れ，部分放電音発生の原 因となるがいし表面での部分放電を抑制するという特徵を 有する。

\section{3. 部分放電音抑制および熱逸走のメカニズム}

〈3.1〉部分放電音抑制と熱逸走に至るメカニズム通 常釉がいしは，污損され雨や霧によって湿潤するとがいし 表面の部分放電により部分放電音が発生することがある。 部分放電は, 污損層に漏れ電流が流れると, 電流密度が高 い部分にジュール熱により形成される局部的な乾燥帯 (高 抵抗部) ができ，この部分に電圧分担が集中するために生 じるがいし沿面の絶縁破壞である。通常釉がいしでは，こ の乾燥帯の形成, 増大, 再湿潤を繰り返すことで継続的な 部分放電音が発生する。このメカニズムを図 2 に示す。

一方, 導電釉がいしでは上記のような部分放電は観測さ れない。これは, 図 3 に示すとおり導電釉がいしの表面に 局部的な乾燥帯が生じても，この部分を流れる漏れ電流は 抵抗の低い導電釉内部を流れるため，電圧分担を緩和し部 分放電の発生を抑制するためである。

さらに，この導電釉内を漏れ電流が流れることで，弚の ジュール熱により，湿潤した污損層を乾燥させる効果もあ り，継続的な部分放電音の発生を抑制する。

導電釉がいしは，このような優れた部分放電音抑制効果 を有する一方で, 過酷な海塩污損環境下でがいしが熱的に 破壞する熱逸走という課題も有している。これは, 導電釉 および磁器の抵抗には次式および図 4 で示されるような負 の温度依存特性があることによる。

$$
\begin{aligned}
& \mathrm{R}(\mathrm{T})= \mathrm{R}_{0} \exp \mathrm{B}\left(1 /(273+\mathrm{T})-1 /\left(273+\mathrm{T}_{0}\right)\right) \\
& \text { ここで }, \mathrm{R}(\mathrm{T}): \text { 温度 } \mathrm{T} \text { のときの抵抗 }(\Omega) \\
& \mathrm{R}_{0}: \text { 温度 } \mathrm{T}_{0} \text { のときの抵抗 }(\Omega)
\end{aligned}
$$

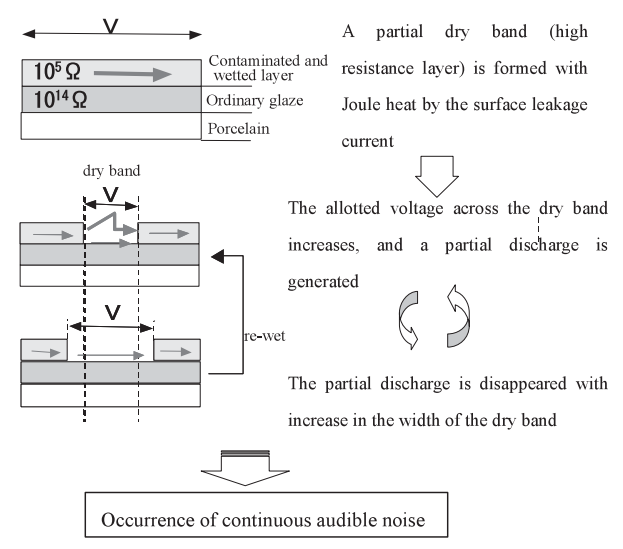

図 2 通常釉がいしの部分放電音発生メカニズム Fig. 2. Mechanism of audible noise due to partial discharge on ordinary glaze insulator.

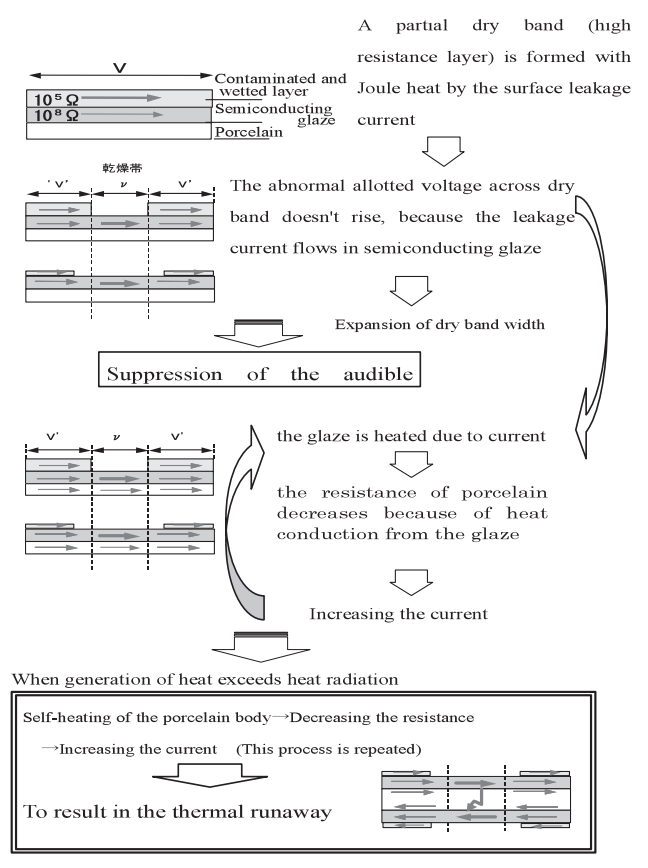

图 3 導電釉がいしの部分放電音抑制および 熱䰠走メカニズム

Fig. 3. Mechanism of audible noise suppression and thermal runaway of semiconducting glaze insulator.

$$
\begin{aligned}
& \mathrm{B} \text { : サーミスタ定数 (K) } \\
& \mathrm{T}_{0} \text { : 初期温度 }\left({ }^{\circ} \mathrm{C}\right) \text { ( }=\text { 周囲温度) }
\end{aligned}
$$

漏れ電流か導電釉内に流れ込むことで発生したジュール 熱により，まず導電婇が発熱する。導電釉の温度上昇に伴 い, 乥の抵抗が低下するとともに, 導電釉の温度か磁器に伝 導し, 磁器の抵抗も同樣に低下する。各々の抵抗が低下す ることで, 漏れ電流か増大し,さらに発熱・温度上昇を繰り 返す。この発熱が放熱と平衡状態にあるうちはいいが，こ れを上回る場合には熱安定性を失い, 磁器自体が発熱・温 度上昇を繰返し，ついには,がいしか熱的破壞に至る。こ の, がいしか熱安定性を失い, 破壊に至る現象を熱逸走と いう。 


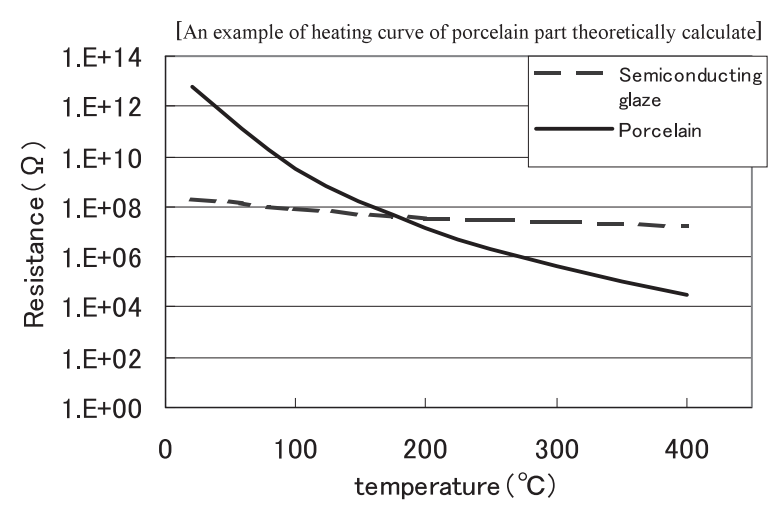

図 4 磁器および導電釉の抵抗一温度特性

Fig. 4. Relation between resistivity and temperature for porcelain and semiconducting glaze.

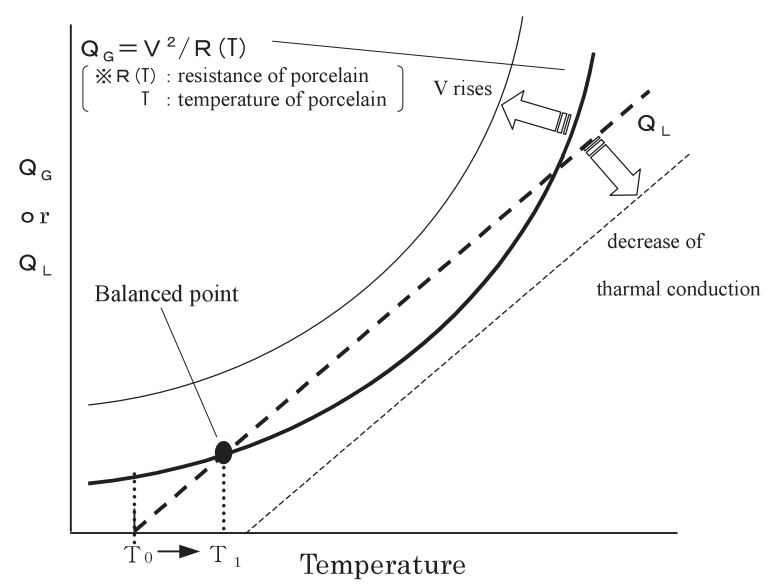

図 5 熱免走とがいしに出入りするエネルギー Fig. 5. Input and output energy of insulator and thermal runaway.

〈3.2〉熱逸走に至る条件 熱逸走を導電釉がいしに出 入りするエネルギーに着目して述べると次のようになる。

がいし表面が清浄な場合, 初期温度 $\mathrm{T}_{0}$ (= 周囲温度)，初 期抵抗値 $\mathrm{R}\left(\mathrm{T}_{0}\right)$ の導電釉がいしに電圧 $\mathrm{V}$ が印加されると, このがいしには単位時間に $\mathrm{Q}_{\mathrm{G}} \quad\left(=\mathrm{V}^{2} / \mathrm{R}(\mathrm{T})\right)$ なるエネル ギーが注入され，これによりジュール熱が発生し，がいし 温度が上昇する。しかし，風雨や大気等により単位時間に 熱放散されるエネルギー $\mathrm{Q}_{\mathrm{L}}$ があるため，がいしの発熱は 熱平衡状態 (図 5 に示す $\mathrm{T}_{1}$ ) となり，温度上昇が停止する と考えられた。

一方, 海水の飛沫に曝されるような污損環境下では, が いし連内の電圧分担に極端なアンバランスを生じることに よる電圧 V の上昇等から熱平衡点を失った場合に，がいし 温度は上昇を続け，熱逸走に至ると考えられる。なお， $\mathrm{Q}_{\mathrm{G}}$ はがいし抵抗値 $\mathrm{R}(\mathrm{T})$ と反比例の関係があることから，導 電釉の初期抵抗值を高抵抗化することにより熱逸走を制御 できる可能性が示唆された。

乥こで, 以降の検討においては, がいし初期抵抗とがい し温度を指標として熱逸走の発生条件の定量化を試みた。
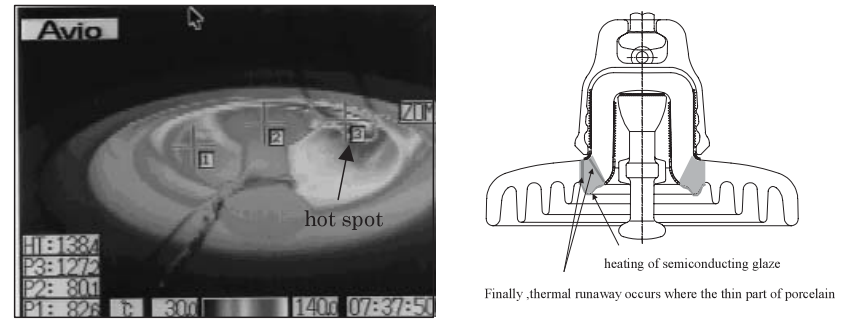

(The thermal image with the infrared rays thermometer)

図 6 導電釉がいしの発熱状況

Fig.6. Surface temperature distribution of semiconducting glaze insulator under thermal runaway.
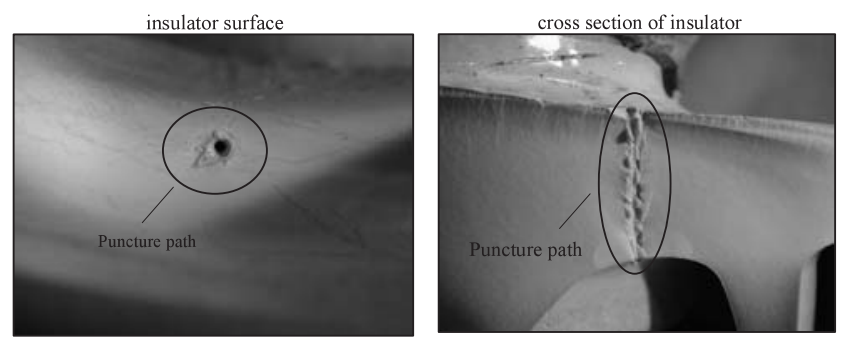

図 7 導電婇がいしの熱逸走状況

Fig. 7. Puncture path due to thermal runaway.

なお， $320 \mathrm{~mm}$ の従来タイプ導電釉がいし 7 個連を耐張 吊りに設置し，がいし下面の方向へ $0.3 \mathrm{~mm} / \mathrm{min}$ の模擬海 水を注水し, 試験電圧 $48 \mathrm{kV}$ ( $=525 \mathrm{kV} / \sqrt{3} \times 7$ 個 $/ 44$ 個) を 印加したところ，熱逸走に至る場合があったことを確認し ている(2)。

また，導電釉がいしの発熱箇所は，図 6 のように漏れ電 流の密度が高いキャップおよびピン周辺付近であることが 多く，熱逸走によるがいし破損状況の一例を図 7 に示す。

\section{4. 高抵抗導電釉がいしの仕様検討}

高抵抗導電釉がいの仕樣検討にあたり，下記について 試験を行って特性を把握し, 評価を行った。

(1) 部分放電音抑制面から見た抵抗值の評価

(2) 熱安定性からみた抵抗值の評価

(3) 磁器の冷熱強度の評価

〈4 1〉 部分放電音抑制面からみた抵抗值の評価 部分 放電音発生のメカニズムから釉薬抵抗は低いほうか望まし い。しかし, 熱逸走防止の面からは釉薬抵抗は高いほうが 望ましい。そこで, 釉薬抵抗をパラメータとして, 部分放 電音抑制効果について下記の試験条件にて確認した結果を 表 1 に示す。

(試験条件) 定印霧中法に準ずる。ただし, 試験電 圧印加 15 分後に人工霧を発生させ, 霧発生から 40 分間漏 れ電流の測定を実施。

試料: $320 \mathrm{~mm}$ 高抵抗導電釉がいし $\times 7$ 個連

印加電圧 : $48 \mathrm{kV}(=525 \mathrm{kV} / \sqrt{3} \times 7$ 個 $/ 44$ 個 $)$

これによると，がいし抵抗值が高くなるにつれて部分放 電音が発生しやすくなる傾向があるが, $900 \mathrm{M} \Omega$ 程度であっ 
表 1 高抵抗導電釉がいしの部分放電音抑制効果 Table 1. Audible noise suppression effect of high resistance semiconducting glaze insulators.

\begin{tabular}{|c|c|c|c|c|c|c|c|c|}
\hline kind of glaze & Ordinary glaze & \multicolumn{6}{|c|}{ High resistance semiconducting glaze } \\
\hline $\begin{array}{c}\text { resistance of } \\
\text { insulator } \\
(\mathrm{M} \Omega / \text { unit })\end{array}$ & \multicolumn{2}{|c|}{$2000 \geqq$} & 200 & \multicolumn{2}{|c|}{380} & 600 & 695 & 904 \\
\hline $\begin{array}{c}\mathrm{ESDD} \\
(\mathrm{NSDD}) \\
\left(\mathrm{mg} / \mathrm{cm}^{2}\right)\end{array}$ & 0.5 & $\begin{array}{c}1.0 \\
(0.1)\end{array}$ & $\begin{array}{c}(0.2) \\
(0.2)\end{array}$ & $\begin{array}{c}0.5 \\
(0.1)\end{array}$ & $\begin{array}{c}1.0 \\
(0.2)\end{array}$ & $\begin{array}{c}1.0 \\
(0.2)\end{array}$ & $\begin{array}{c}1.0 \\
(0.2)\end{array}$ & $\begin{array}{c}1.0 \\
(0.2)\end{array}$ \\
\hline $\begin{array}{c}\text { Occurrence of } \\
\text { partial } \\
\text { discharge }\end{array}$ & $\times$ & $\times$ & $\bigcirc$ & $\bigcirc$ & $\bigcirc^{*}$ & $\bigcirc^{*}$ & $\bigcirc^{* *}$ & $\bigcirc^{* *}$ \\
\hline
\end{tabular}

(注) $\bigcirc^{*}$ : partial discharge occurs at initial stage of moisture (no problem for practical use), which disappears for a short time

$\bigcirc^{* *}$ : partial discharge occurs just after initial wetting and intermittent discharge is observed and several times in measuring duration (no problem for practical use)

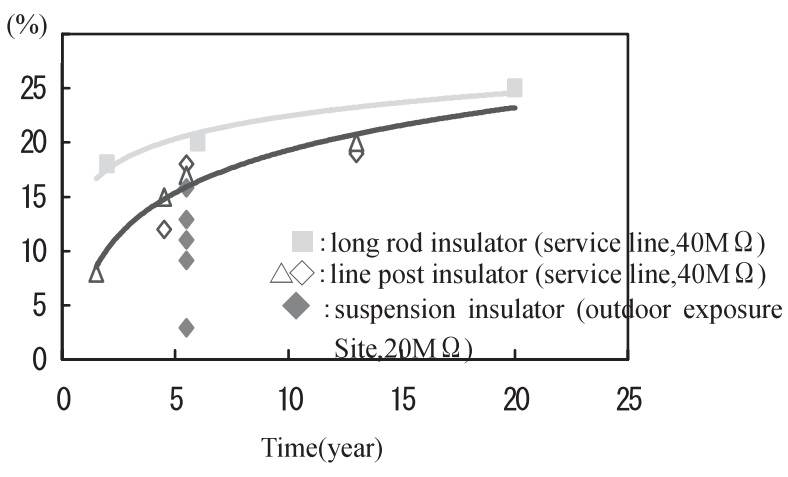

図 8 各種導電釉がいし抵抗増加率の経年変化 (実フィールド)

Fig. 8. Increase rate of DC resistance of various semiconducting glaze insulators in the field.

ても継続的な部分放電音が発生することはなく実用上問題 はない。しかしながら，十分な部分放電音抑制効果を得る ためには，湿潤初期に部分放電音が発生するものの短時間 でこれが消失することを確認した $600 \mathrm{M} \Omega$ 程度以下に，が いし抵抗值を抑える必要があると考えられる。

また, 高抵抗導電婇がしは, 長期間使用すると, 導電 釉層と湿潤した污損層周辺との間で生じる極微少な放電に より釉薬表面が劣化し荒れてくる。光の結果，抵抗値か増 加する。

したがって，劣化が極端に進んで抵抗值が大幅に増加す ると，高抵抗導電釉がいしの部分放電抑制効果に影響を及ぼ すことか懸念されるため,この劣化特性について評価した。

実フィールドにおいて, 各種導電釉がいしの抵抗值につ いて, 光の経年変化を锶測した結果を図 8 に示す。これに よると, 従来タイプ導電釉がいしは, $33 \mathrm{kV}$ 配電線の長幹が いしより,やや抵抗増加率が小さい傾向にある。この $33 \mathrm{kV}$ 配電線の長幹がいしでは, 抵抗増加率は経年 15 年以降飽 和傾向を示し，20 年経過しても $25 \%$ 以下の増加率であるこ とから, 導電釉の劣化という点では, 従来タイプ導電釉が

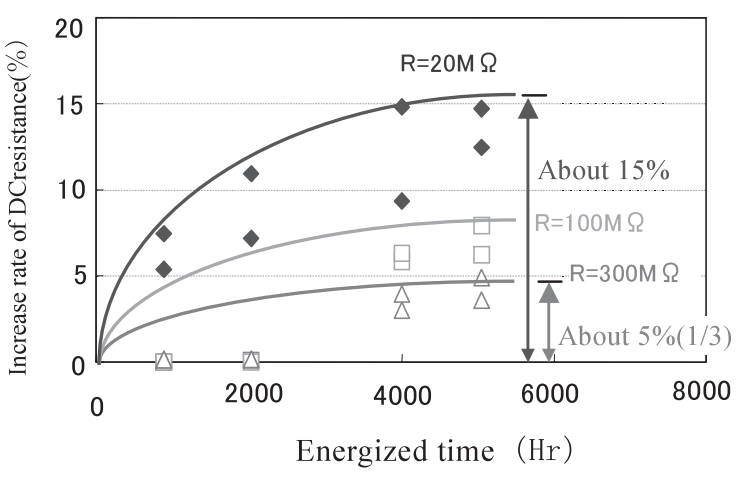

图 9 課電時間-抵抗増加率の関係

Fig. 9. Relation between energized time and increasing ratio of DC resistance.

いしの抵抗増加率も同樣に 20 年経過しても $25 \%$ 以下と推 定される。

また， $\phi 22 \mathrm{~mm}$ の円柱形テストピースを用いて，課電時 間と抵抗増加率との関係を確認したところ, 図 9 に示すと おり，抵抗值が高くなるほど抵抗増加率は低くなる傾向に あり,課電時間が 5000 時間を超えたあたりでは, 初期抵抗 值が低い $20 \mathrm{M} \Omega$ のものは抵抗増加率が約 15\%なのに対し， 高抵抗の $300 \mathrm{M} \Omega$ のものは約 5\%で，抵抗増加率は 3 分の 1 に抑制されていた。これは，高抵抗化により漏れ電流を 抑制することで導電釉層と污損層周辺との間で生じる極微 小な放電による釉薬表面の荒れが抑制されたものと考えら れる。

これらの実フィールドおよび円柱形テストピースでの抵 抗值の経年特性から，高抵抗導電釉の抵抗増加率を見積もる と， $25 \% / 20$ 年 $\times 1 / 3 \times 50$ 年 $=$ 約 $20 \%$ より，50 年で $20 \%$ 程 度と想定される。よって釉薬の劣化を織り込んでも部分放 電抑制効果を消失しない抵抗値として上限值を $500 \mathrm{M} \Omega$ と 評価できると考えた。

〈4.2〉熱安定性からみた抵抗值の評価導電釉がいし への注入エネルギーが熱放散エネルギーを上回った場合， 導電釉がいしは熱安定性限界を超えて熱逸走に至る。

光こで，以下の熱安定性限界試験および熱安定性確認試 験を行い，熱逸走の条件を確認するとともに，釉薬抵抗の 下限值を評価した。

（1）熱安定性限界試験 直流抵抗值 100 $360 \mathrm{M} \Omega$ 程 度の $320 \mathrm{~mm}$ 高抵抗導電釉がいしを試作し, 注入エネルギー 量を増加させる条件で熱安定性限界試験を実施した。すな わち, 設計電圧を上回る電圧を印加する等の条件で塩水注 水試験を実施し，強制的に熱逸走を発生させ，これにより 污損湿潤状態て導電釉がいしが破損する最低温度および熱 逸走への進展か認められず，がいし破損が発生しない最高 温度〔許容温度〕を赤外線温度計により調べた。試験条件 を表 2 , 試験結果を図 10 に示す。

これより，導電釉がいしの污損湿潤条件での熱安定性限 界は,がいし温度を指標として以下のとおりであった。 がいし破損発生時の最低温度上昇值 : $+110 \mathrm{~K}$ 


\section{表 2 試験条件}

Table 2. Test conditions.

\begin{tabular}{|l|l|}
\hline sample & $\begin{array}{l}320 \mathrm{~mm} \text {-high resistance semiconducting glaze } \\
\text { insulator(1 } \sim 7 \text {-units string) }\end{array}$ \\
\hline $\begin{array}{l}\text { salt water } \\
\text { density(weight\%) }\end{array}$ & $\begin{array}{l}\text { The amount of } \mathrm{NaCl} \text { and } \mathrm{MgCl}_{2} \text { is } 3 \% \text { of total } \\
\text { weight (The ratio of } \mathrm{MgCl} 2 \text { is } 16 \sim 48 \%)\end{array}$ \\
\hline $\begin{array}{l}\text { direction of } \\
\text { precipitation }\end{array}$ & $45^{\circ}$ toward a lower side of insulator \\
\hline $\begin{array}{l}\text { precipitation } \\
\text { condition }\end{array}$ & $\begin{array}{l}\text { uniformly , un-uniformly (precipitation rate } \\
\text { was reduced at the line side unit in a string) }\end{array}$ \\
\hline $\begin{array}{l}\text { initial temperature } \\
\text { of insulator }\end{array}$ & room temperature $\sim 40^{\circ} \mathrm{C}$ \\
\hline test voltage ( $\mathrm{kV})$ & $6.9 \sim 40 \mathrm{kV} /$ unit \\
\hline test duration & 1 hour ( continued for 8 hours in long time test) \\
\hline
\end{tabular}

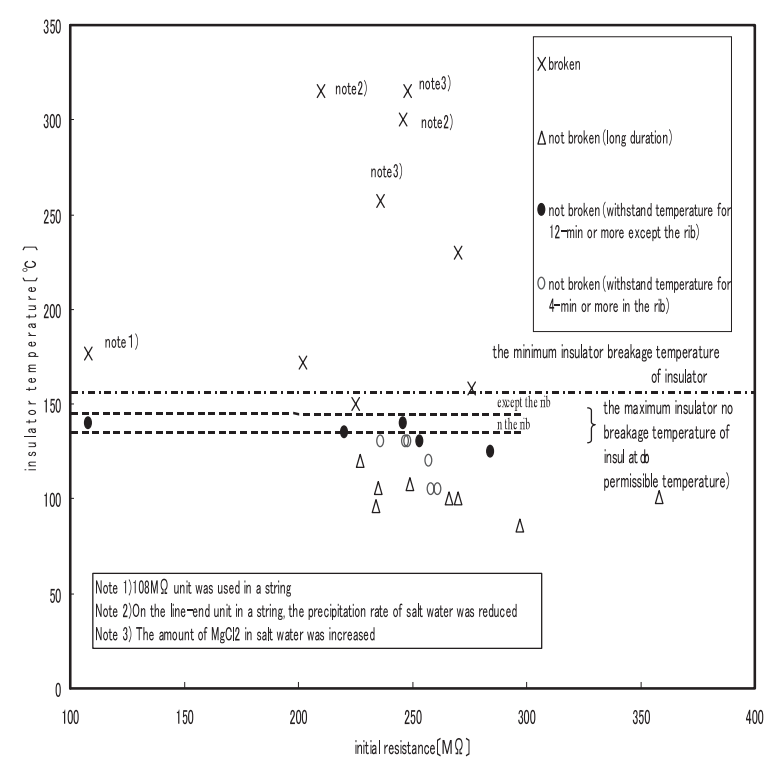

図 10 高抵抗導電釉がいしのがいし温度-初期抵抗特性

Fig. 10. Initial DC resistance of high resistance semiconducting glaze insulators and surface temperature.

\section{表 3 熱安定性限界試験におけるフラッシオーバの先行}

Table 3. Occurrence of flashovers in the critical thermal stability tests.

\begin{tabular}{|c|c|c|c|c|c|}
\hline Item number of unit in $_{\text {a string }}^{\text {numb }}$ & 5 & 7 & 7 & 9 & 44 \\
\hline $\begin{array}{l}\text { Test voltage/design voltage } \\
\text { (times) }\end{array}$ & 1. 3 & 1. 3 & 1.2 & 1.3 & 1.4 \\
\hline 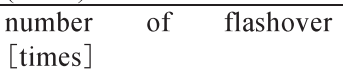 & 1 & 3 & 2 & 1 & 1 \\
\hline
\end{tabular}

(がいし破損発生した最低温度 $150^{\circ} \mathrm{C}$ - 設計周囲温度 $40^{\circ} \mathrm{C}$ )

許容温度上昇値 : $+90 \mathrm{~K}$

(がいし破損が発生しなかった最高温度 $130^{\circ} \mathrm{C}$ - 設計周 囲温度 $40^{\circ} \mathrm{C}$ )

なお，先に述べた熱安定性限界試験において，海水しぶ きが全体的にかかる (均一注水) 条件下で, 表 3 のとおり 設計電圧 $6.9 \mathrm{kV} /$ 個 (= $525 \mathrm{kV} / \sqrt{3} / 44$ 個) を上回る電圧を 印加し，強制的にがいしの熱逸走を試みたところ，熱逸走 は発生せずフラッシオーバが先行した。

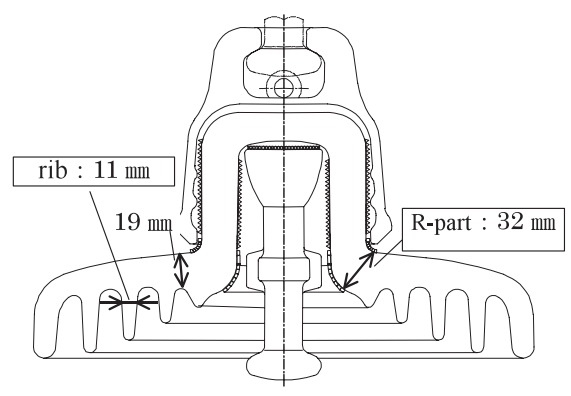

図 $11320 \mathrm{~mm}$ 高抵抗導電釉がいしの各部寸法 (熱逸走発生箇所の磁器厚さ)

Fig. 11. Dimensions of $320 \mathrm{~mm}$ high resistance semiconducting glaze insulator (thickness of porcelain where thermal runaway may happen).

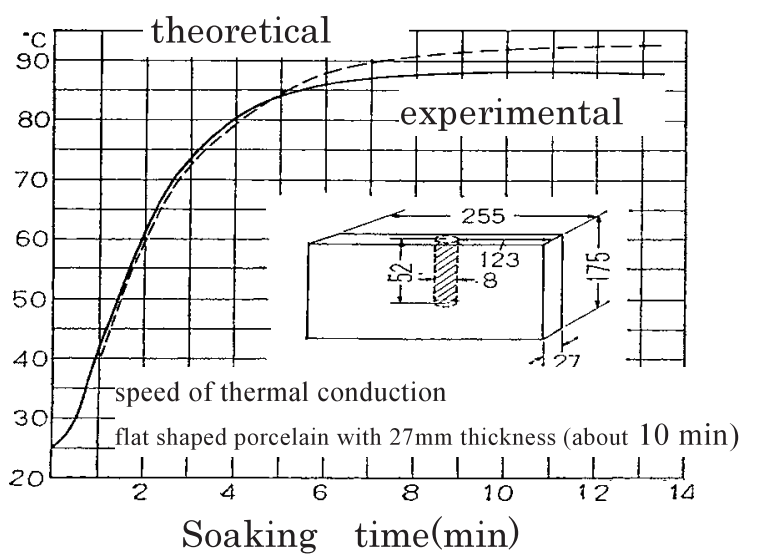

図 12 がいしの熱伝導特性 (厚さ $27 \mathrm{~mm}$ の平板磁器) ${ }^{(4)}$

Fig. 12. Heat conduction characteristics of porcelain (porcelain plate with $27 \mathrm{~mm}$ thickness) ${ }^{(4)}$.

さらに, 通常考えにくいものの, 周囲温度 $40^{\circ} \mathrm{C} \cdot$ 無風状 態て課電側のがいし 1 個のみ塩水注水量を減らした (不均 一注水) 条件下では熱逸走が発生し，笠欠けに至った。た だし，この場合でも，後述するように風速 $8 \mathrm{~m} / \mathrm{s}$ のもとで は，がいし温度上昇か抑制され熱逸走には至らなかった。

ここで, がいし温度指標の設定について詳しく述べるこ ととする。

がいし温度については, 試験制約上, 表面温度の測定の みを実施していることから，がいし表面の温度が，がいし 内部まで十分に熱伝導されていると考えられる時間および 温度を以下のとおりと考えた。

がい各部の寸法および熱伝導特性は图 11 , 图 12 に示 すとおりであり，熱伝導時間は磁器厚さに比例すると考え られ，図 12 に示すとおり $27 \mathrm{~mm}$ 厚さでは約 10 分で内部 まで熱伝導していることから，がいし内部まで十分に熱伝 導される時間は下記のとおり設定した。

リブ部以外 : 12 分以上

$$
\text { (10 分 } \div 27 \mathrm{~mm} \times 32 \mathrm{~mm} \doteqdot 12 \text { 分) }
$$

リブ部：4 分以上

(10 分 $\div 27 \mathrm{~mm} \times 11 \mathrm{~mm} \div 4$ 分)

前記の時間を指標として，がいし内部まで十分に熱伝導 
し，かつ熱逸走への進展か認められなかったがいし表面温 度データを調査した結果, 上限は図 13 のとおりであった。 これより，許容温度を下記のとおり定めた。

許容温度 リブ部以外 : $140^{\circ} \mathrm{C}$

$$
\text { リブ部 }: 130^{\circ} \mathrm{C}
$$

なお, 設計周囲温度は架空送電線の電流容量設計等で用 いられている $40^{\circ} \mathrm{C}$ を採用した ${ }^{(3)}$ 。

（2）熱安定性確認試験高抵抗導電釉がしでは, 釉 薬抵抗值を低く設定しすぎると漏れ電流が大きくなり熱逸 走を生じやすいため，抵抗値をできるだけ高く設定する必 要がある。〈4・1〉で設定した上限值 $500 \mathrm{M} \Omega$ から製造上の 釉薬配合や厚さの変動 $\pm 30 \%$ 程度を考慮した抵抗の下限値 は $250 \mathrm{M} \Omega$ となる。

乥こで,想定される使用条件下で, 抵抗值 $250 \mathrm{M} \Omega$ 程度の 高抵抗導電婇がいしの最高温度を測定し, 上記の許容温度 上昇值との比較を実施した。試験条件を表 4 , 結果を図 14 および図 15 に示す。

塩水注水時において, 5〜9個/連の無風状態では, がいし 温度か許容温度上昇值を上回ることがあったものの，7 個/ 連の風速 $8 \mathrm{~m} / \mathrm{s}$ の試験結果では温度上昇は 20〜 $40 \mathrm{~K}$ に抑制 された。また，15〜44 個/連の無風状態では, 許容温度上

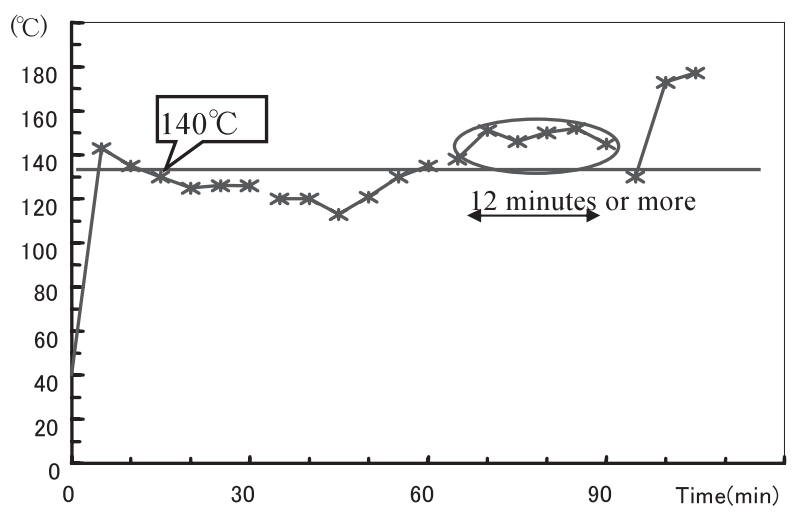

(a) Not rib

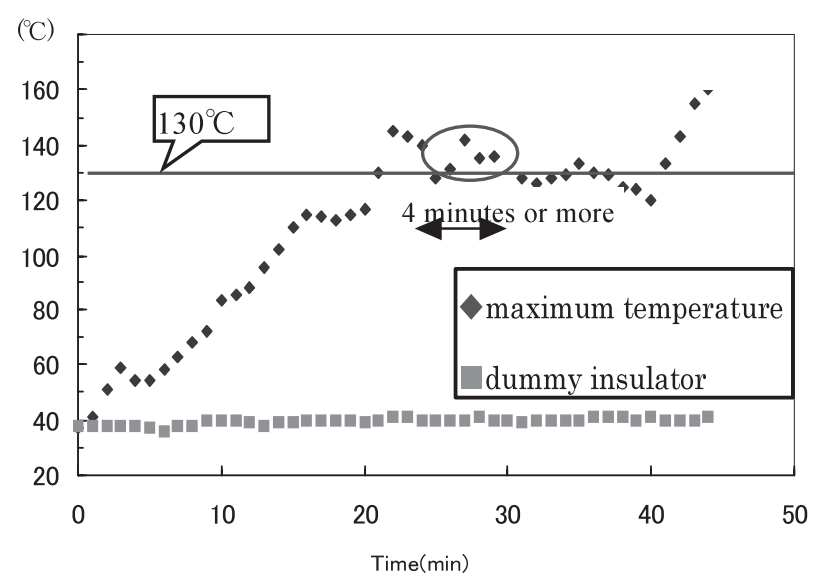

(b) Rib

図 13 がいし表面温度の時間変化

Fig. 13. Surface temperature of insulator with elapsed time.
昇値を下回り, 図 15 に示す 7 個/連の試験結果から, 有風 時にはさらに温度上昇が抑制されることが期待できる。

さらに，7 個連，22 個連の污損湿潤時においても，がい し温度は許容温度上昇值を下回ったことを確認した。

したがって, 高抵抗導電釉がいしが許容温度上昇值を上 回るのは, 無風状態で実施した 5〜9個/連の塩水注水試験 のみであり，この場合でも風速 $8 \mathrm{~m} / \mathrm{s}$ があれば温度上昇は 20〜 $40 \mathrm{~K}$ 程度に抑えられた。気象庁風力階級表にも記され

表 4 試験条件

Table 4. Test conditions.

Osalt water test

\begin{tabular}{|c|c|}
\hline sample & $\begin{array}{l}320 \mathrm{~mm} \text {-high resistance semiconducting } \\
\text { glaze insulator( } 5 \sim 44 \text {-units string) }\end{array}$ \\
\hline $\begin{array}{l}\text { salt water } \\
\text { density }(\text { weight } \%)\end{array}$ & $\begin{array}{l}\text { The amount of } \mathrm{NaCl} \text { and } \mathrm{MgCl}_{2} \text { is } 3 \% \text { of } \\
\text { total weight (The ratio of } \mathrm{MgCl} 2 \text { is } 16 \% \text { ) }\end{array}$ \\
\hline $\begin{array}{ll}\text { direction } & \text { of } \\
\text { precipitation } & \\
\end{array}$ & $45^{\circ}$ toward a lower side of insulator \\
\hline $\begin{array}{l}\text { precipitation } \\
\text { condition }\end{array}$ & $\begin{array}{l}\text { uniformly (un-uniformly in the case of } \\
\text { wind blowing) }\end{array}$ \\
\hline $\begin{array}{l}\text { initial temperature } \\
\text { of insulator }\end{array}$ & $40^{\circ} \mathrm{C}$ \\
\hline velocity of the wind & no wind $、 8 \mathrm{~m} / \mathrm{s}$ \\
\hline test voltage $(\mathrm{k} \mathrm{V})$ & $\begin{array}{l}6.9 \mathrm{kV} / \text { unit (in case of } 44 \text {-units string, } \\
\text { maximum applied voltage is } 1.3 \text { times of } \\
500-\mathrm{kV} \text { operating voltage) }\end{array}$ \\
\hline test duration & $\begin{array}{l}1 \text { hour (long time duration test was made } \\
\text { for } 8 \text { hours) }\end{array}$ \\
\hline
\end{tabular}

Oclean fog method examination

\begin{tabular}{|l|l|}
\hline Sample & $\begin{array}{l}320 \mathrm{~mm} \text {-high resistance semiconducting } \\
\text { glaze insulator(7,22-units string) }\end{array}$ \\
\hline ESDD、NSDD & ESDD $1.0 \mathrm{mg} / \mathrm{cm}^{2}$ (The ratio of MgCl2 is \\
& $\begin{array}{l}16 \%) \\
\text { NSDD } 0.2 \mathrm{mg} / \mathrm{cm}^{2}\end{array}$ \\
\hline $\begin{array}{l}\text { initial temperature } \\
\text { of insulator }\end{array}$ & $40^{\circ} \mathrm{C}$ \\
\hline test voltage $(\mathrm{k} \mathrm{V})$ & $6.9 \mathrm{kV} /$ unit \\
\hline
\end{tabular}

Note)the other condition was done by the clean fog method

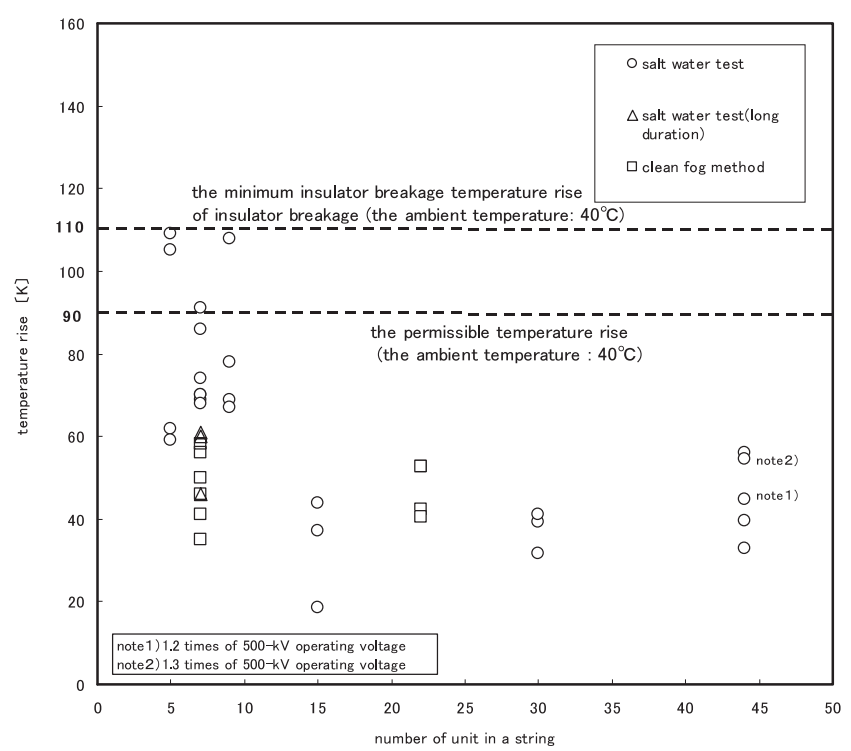

図 14 熱安定性試験におけるがいし温度特性 (無風時)

Fig. 14. Temperature rise of insulators in thermal stability verification test (no-wind). 
ているとおり，海水しぶきがかかる条件下では風速 $10 \mathrm{~m} / \mathrm{s}$ を超えることが十分期待できるため，実フィールドにおい て, 高抵抗導電釉がいしか熱逸走することはないと評価で きると考えられる。よって，釉薬抵抗の下限值は $250 \mathrm{M} \Omega$ として問題ないと考えられる。

〈 4 3 > 磁器の冷熱強度の評価高抵抗導電釉がいし では，通常釉がいでは見られないようながいし温度とな ることがあるため，がいし発熱時に突然の降雨等により急 冷された場合を想定する必要がある。光こで，高温にした がいし冷水に浸し,がいし磁器の限界冷熱強度を調へた。 結果を表 5 に示す。

これより，限界冷熱強度は傷の内容 (取扱い傷等) によ り低下するものの，最低破壞温度差が $130 \mathrm{~K} て ゙ あ り ，$ 温度 差 $90 \mathrm{~K}$ 以下では破壊しないことを確認した。

また，熱逸走付近まで高温にしたがいしを冷水に浸し急 冷する (温度差 $120 \mathrm{~K}$ ) ことを 50 回繰り返し, 試験後に限 界冷熱強度を実施した結果, 初期強度と同等以上の強度を 有していることを確認した。

さらに，想定される使用条件下の豪雨 (降雨量の国内最大 記録より $5 \mathrm{~mm} /$ 分) を模擬した注水冷熱試験では，冷熱温度 差が $30 \mathrm{~K}$ 向上することを確認した。よって，実使用条件下に

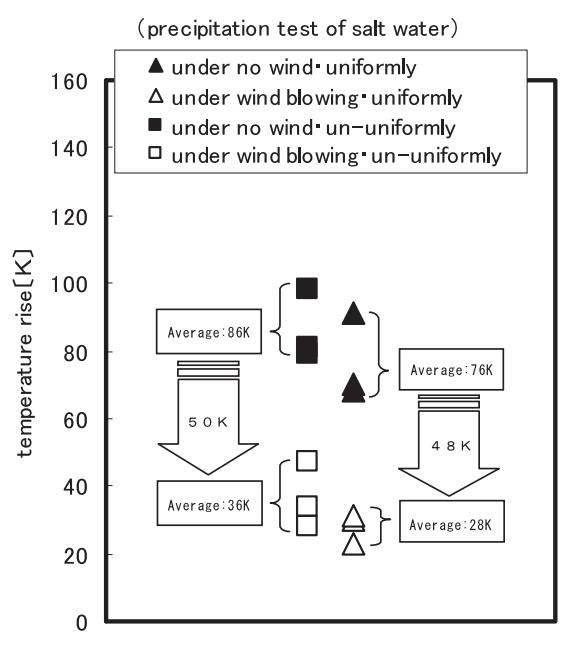

図 15 風によるがいし温度上昇の抑制効果

Fig. 15. Reduction of temperature rise of insulator by wind.

\section{表 5 がいし磁器の限界冷熱強度}

Table 5. Critical thermal shock strength of porcelain.

\begin{tabular}{|c|c|c|c|c|}
\hline \multicolumn{2}{|c|}{ Sample insulators } & $\begin{array}{c}\text { content of the } \\
\text { damage }\end{array}$ & $\begin{array}{l}\text { temperature } \\
\text { difference }[\mathrm{K}]\end{array}$ & $\begin{array}{c}\text { minimum } \\
\text { temperature } \\
\text { difference }[\mathrm{K}]\end{array}$ \\
\hline \multicolumn{2}{|c|}{ 320mm suspension (new) } & \multirow{3}{*}{ no damage } & \multirow{3}{*}{$110 \sim 180$} & 170 \\
\hline \multicolumn{2}{|c|}{ 250mm Fog type(new) } & & & 170 \\
\hline \multicolumn{2}{|c|}{ 400mm Fog type(new) } & & & 160 \\
\hline \multirow{3}{*}{$\begin{array}{c}320 \mathrm{~mm} \\
\text { suspen } \\
\text {-sion }\end{array}$} & $\begin{array}{l}\text { after outdoor } \\
\text { examination } \\
\text { (5.5years) }\end{array}$ & $\begin{array}{c}\text { Pitting } \\
\text { +handling } \\
\text { damage }\end{array}$ & \multirow[t]{2}{*}{$70 \sim 160$} & 140 \\
\hline & $\begin{array}{l}\text { an artificially } \\
\text { damaged }\end{array}$ & $\begin{array}{c}\text { mock of the } \\
\text { handling damage }\end{array}$ & & 160 \\
\hline & $\begin{array}{c}\text { after the } \\
\text { examination }\end{array}$ & $\begin{array}{c}\text { Handling } \\
\text { damage }\end{array}$ & $100 \sim 160$ & 130 \\
\hline
\end{tabular}

おいては,高抵抗導電釉がいしは温度差 $130 \mathrm{~K}+30 \mathrm{~K}=160 \mathrm{~K}$ まで泠熱破壞しないと想定される。

以上のとおり, がいし磁器の冷熱強度は, $\langle 4 \cdot 2\rangle(1)$ で評 価した許容温度上昇值 $(+90 \mathrm{~K})$ を大きく上回ることから， 従来どおり丁寧にがいしを取扱うことで, がいしの冷熱破 壞等の問題はないと考えられる。

\section{5. フィールド性能検証}

高抵抗導電釉がいしを $275 \mathrm{kV}$ 送電線 $(280 \mathrm{~mm}$ 高抵抗導電 釉 26 個 $\times 2$ 連, 設計ESDD $1.0 \mathrm{mg} / \mathrm{cm}^{2}$ ) および $77 \mathrm{kV}$ 送電線 $\left(250 \mathrm{~mm}\right.$ 高抵抗導電釉 8 個 $\times 2$ 連, 設計 ESDD $\left.0.5 \mathrm{mg} / \mathrm{cm}^{2}\right)$ に取り付け,フィールドにおける多樣な污損湿潤状況での 熱逸走抑制効果および部分放電抑制効果について, 平成 13 年から平成 15 年までの約 2 年にわたり観測した。

(1) $275 \mathrm{kV}$ 送電線(設計 ESDD $1.0 \mathrm{mg} / \mathrm{cm}^{2}$ ) $275 \mathrm{kV}$ 送電線においては，集音マイク，カメラ，VTR 等て構成され， 部分放電音の発生をトリガーに動作する観測装置を図 16 の ように設置して，高抵抗導電釉がいし連および通常釉がい し連を常時観測するとともに，塔体内に設置したパイロッ 卜がいしの塩分付着量を定期的に測定し，気象データと合 わせ分析に活用した。

さらに, 台風接近通過後等には, 夜間に赤外線温度計を 用いたがいし表面温度観測と暗視カメラを用いた部分放電 観測を実施した。

夜間観測結果を表 6 に示す。表 6 のとおり高抵抗導電釉 がいに特異な発熱ならびに部分放電の発生はなかった。 また，観測期間中連続監視を行った部分放電音も発生しな かったことが確認できた。

なお，常時污損に対するパイロットがいしの塩分付着量 は定期的にしか確認できない。光こで，観測期間中の最大 塩分付着密度を, 定期測定の塩分付着密度および連続して $5 \mathrm{~mm}$ 以上の降水がなかった期間の最大風程から塩分付着 量は風程 $(\Sigma \mathrm{Vt})$ にほぼ比例すると想定し, 塩分付着密度を

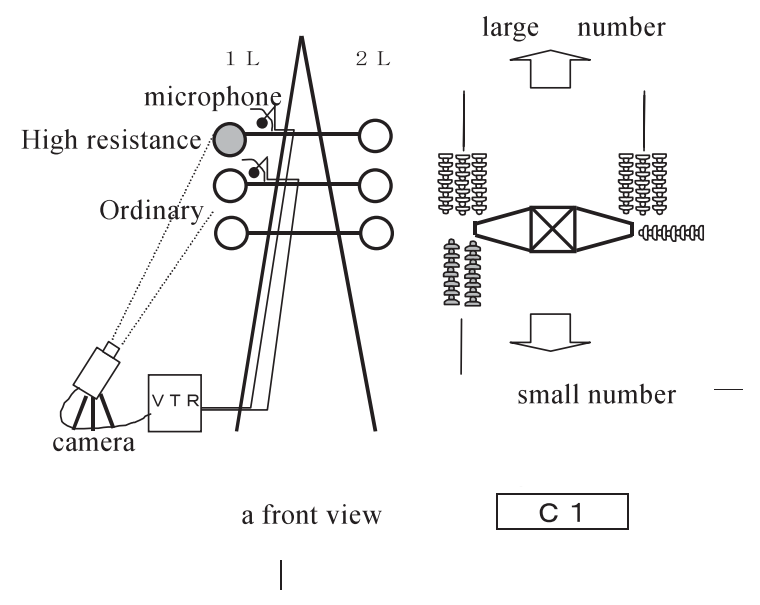

図 16 部分放電観測状況図 (275 kV 送電線)

Fig. 16. Observation of partial discharge on $275 \mathrm{kV}$ transmission line. 
表 6 送電線夜間観測結果 $(275 \mathrm{kV}$ 送電線)

Table 6. Night observation results on $275 \mathrm{kV}$ transmission line.

\begin{tabular}{|c|c|c|c|c|c|c|c|}
\hline \multirow{2}{*}{$\begin{array}{l}\text { date, time } \\
\text { 【remarks】 }\end{array}$} & \multirow{2}{*}{$\underset{\left(m g / \mathrm{cm}^{2}\right)}{\mathrm{ESDD}}$} & \multirow{2}{*}{$\begin{array}{l}\text { kind of } \\
\text { insulatoro }\end{array}$} & \multirow{2}{*}{$\begin{array}{c}\text { Meteorologi } \\
\text {-al } \\
\text { conditions }\end{array}$} & \multirow{2}{*}{\begin{tabular}{|c|}
$\begin{array}{c}\text { temperature } \\
\text { distribution of } \\
\text { a string }\end{array}$ \\
$\begin{array}{r}\text { line } s \text { idea } ~ \\
\text { center } \sim \text { carth } \\
\text { side }\end{array}$ \\
\end{tabular}} & \multirow{2}{*}{\begin{tabular}{|c|c|} 
(reference) \\
sufface \\
temperature \\
of tower \\
components \\
\end{tabular}} & \multicolumn{2}{|c|}{$\begin{array}{l}\text { Night observation of partial } \\
\text { discharge }\end{array}$} \\
\hline & & & & & & $\begin{array}{c}\text { visual } \\
\text { inspection }\end{array}$ & $\begin{array}{l}\text { the darkness } \\
\text { camera }\end{array}$ \\
\hline \multirow{2}{*}{$\begin{array}{l}\text { Augunst.23,2001 } \\
\text { About 18:45 } \\
\text { Ityphoon } \\
\text { No.0111] }\end{array}$} & \multirow{2}{*}{$\begin{array}{l}\text { upper surface: } \\
0.002 \text { love: } \\
\text { lowersurfe: } \\
0.004\end{array}$} & $\begin{array}{c}\text { High } \\
\text { resistance } \\
\text { glaze }\end{array}$ & \multirow{2}{*}{$\begin{array}{l}25.5^{\circ} \mathrm{C} \\
81 \% \\
\text { breeze }\end{array}$} & $\begin{array}{r}25.0^{\circ} \mathrm{C} \sim \\
25.8^{\circ} \mathrm{C} \\
\end{array}$ & \multirow{2}{*}{$\begin{array}{r}25.0^{\circ} \mathrm{C} \sim \\
25.5^{\circ} \mathrm{C}\end{array}$} & No & No \\
\hline & & $\begin{array}{c}\text { Ordinary } \\
\text { glaze }\end{array}$ & & $\begin{array}{l}25.0^{\circ} \mathrm{C} \sim \\
25.4^{\circ} \mathrm{C}\end{array}$ & & No & No \\
\hline \multirow{2}{*}{$\begin{array}{c}\text { July.12,2002 } \\
\text { About } 19.25 \\
\text { Ittphoon } \\
\text { No.0206] }\end{array}$} & \multirow{2}{*}{$\begin{array}{l}\text { upper sufface: } \\
\text { 0.003 } \\
\text { lower surface: } \\
0.015\end{array}$} & $\begin{array}{c}\text { High } \\
\text { resistance } \\
\text { glaze }\end{array}$ & \multirow{2}{*}{$\begin{array}{l}28.0^{\circ} \mathrm{C} \\
74 \% \\
1.8 \sim \\
2.4 \mathrm{~m} / \mathrm{s}\end{array}$} & $\begin{array}{r}22.3^{\circ} \mathrm{C} \\
22.9^{\circ} \mathrm{C} \\
\end{array}$ & \multirow{2}{*}{$\begin{array}{r}22.3^{\circ} \mathrm{C} \sim \\
23.4^{\circ} \mathrm{C}\end{array}$} & No & No \\
\hline & & $\begin{array}{c}\text { Ordinary } \\
\text { glaze }\end{array}$ & & $\begin{aligned} 22.1^{\circ} \mathrm{C} & \sim \\
22.8^{\circ} \mathrm{C} & \end{aligned}$ & & No & No \\
\hline \multirow{2}{*}{$\begin{array}{l}\text { October.4,2002 } \\
\text { About } 1600 \\
\text { Ityphoon } \\
\text { No.0221] }\end{array}$} & \multirow{2}{*}{$\begin{array}{c}\text { upper surface: } \\
0.000 \\
\text { lower surface: } \\
0.013\end{array}$} & $\begin{array}{c}\text { High } \\
\text { resistatce } \\
\text { glaze }\end{array}$ & \multirow{2}{*}{$\begin{array}{l}27.5^{\circ} \mathrm{C} \\
60 \% \\
2.5 \mathrm{~m} / \mathrm{s}\end{array}$} & $\begin{aligned} 22.8^{\circ} \mathrm{C} & \sim \\
23.6^{\circ} \mathrm{C} & \end{aligned}$ & \multirow{2}{*}{$\begin{array}{r}24.0^{\circ} \mathrm{C} \sim \\
242^{\circ} \mathrm{C}\end{array}$} & $\begin{array}{c}\text { Not } \\
\text { observe }\end{array}$ & $\begin{array}{c}\text { Not } \\
\text { observe }\end{array}$ \\
\hline & & $\begin{array}{c}\text { Ordinary } \\
\text { glaze }\end{array}$ & & $\begin{array}{l}23.1^{\circ} \mathrm{C} \sim \\
23.7^{\circ} \mathrm{C}\end{array}$ & & $\begin{array}{c}\text { Not } \\
\text { observe }\end{array}$ & $\begin{array}{c}\text { Not } \\
\text { observe }\end{array}$ \\
\hline \multirow[t]{2}{*}{$\begin{array}{l}\text { January } 30,2003 \\
\text { About } 18: 00\end{array}$} & \multirow{2}{*}{$\begin{array}{l}\text { upper surface: } \\
\text { o.011 } \\
\text { lower surface: } \\
0.017\end{array}$} & $\begin{array}{c}\begin{array}{c}\text { High } \\
\text { resistance } \\
\text { glaze }\end{array} \\
\end{array}$ & \multirow{2}{*}{$\begin{array}{l}1.4^{\mathrm{C}} \mathrm{C} \\
61 \% \\
0.3 \mathrm{~m} / \mathrm{s}\end{array}$} & $0.5^{\circ} \mathrm{C} \sim{ }_{0.9^{\circ} \mathrm{C}}$ & \multirow{2}{*}{$-1.3^{\circ} \mathrm{C} \sim$} & No & No \\
\hline & & $\begin{array}{c}\text { Ordinary } \\
\text { glaze }\end{array}$ & & $0.7^{\circ} \mathrm{C} \sim{ }_{1.1^{\circ} \mathrm{C}}$ & & No & No \\
\hline \multirow[t]{2}{*}{$\begin{array}{l}\text { April.17,2003 } \\
\text { About 19:00 }\end{array}$} & \multirow{2}{*}{$\begin{array}{c}\text { upper sufface: } \\
\text { s.004 } \\
\text { lower surface: } \\
0.011\end{array}$} & $\begin{array}{c}\begin{array}{c}\text { High } \\
\text { resistance } \\
\text { glaze }\end{array} \\
\end{array}$ & \multirow{2}{*}{$\begin{array}{l}17.5^{\circ} \mathrm{C} \\
66 \% \% \\
0.5 \sim \\
0.8 \mathrm{~m} / \mathrm{s}\end{array}$} & $\begin{array}{r}13.4^{\circ} \mathrm{C} \sim \\
140^{\circ} \mathrm{C}\end{array}$ & \multirow{2}{*}{$\begin{array}{r}13.4^{\circ} \mathrm{C} \sim \\
13.6^{\circ} \mathrm{C}\end{array}$} & No & No \\
\hline & & $\begin{array}{c}\text { Ordinary } \\
\text { glaze } \\
\end{array}$ & & $13.6^{\circ} \mathrm{C} \sim \mathrm{C}^{\circ} \mathrm{C}$ & & No & No \\
\hline
\end{tabular}

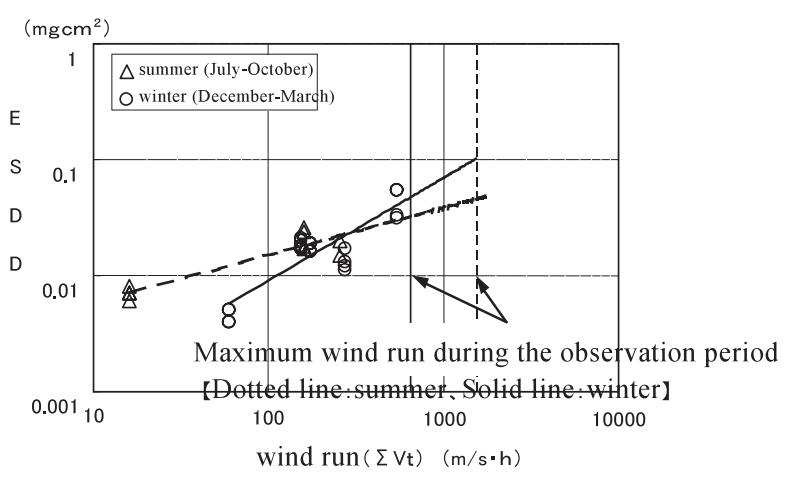

図 17 最大塩分付着密度の推定 (275 kV 送電線)

Fig. 17. Maximum ESDD on $275 \mathrm{kV}$ transmission line.

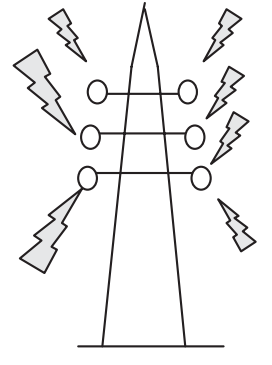

Tower (ordinary glaze)

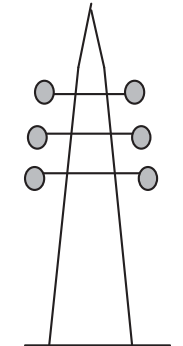

Tower (high resistance glaze)
図 18 部分放電観測状況図 (77 kV 送電線)

Fig. 18. Observation of partial discharge on $77 \mathrm{kV}$ transmission line.

推定したところ図 17 のとおりであった。

これより, $275 \mathrm{kV}$ 送電線では, 冬期 (12〜3 月) におい て観測期間中の最大塩分付着 $0.1 \mathrm{mg} / \mathrm{cm}^{2}$ と推定され，この 污損・湿潤環境下で, 部分放電の発生がなかったと考えら れる。

(2) $77 \mathrm{kV}$ 送電線 (設計 ESDD $0.5 \mathrm{mg} / \mathrm{cm}^{2}$ ) $\quad 77 \mathrm{kV}$ 送電線において, 図 18 のように高抵抗導電釉がいし連の鉄 塔および隣接する通常釉懸垂がいし連の鉄塔について, 部

\section{表 7 夜間観測結果 $(77 \mathrm{kV}$ 送電線)}

Table 7. Night observation results on $77 \mathrm{kV}$ transmission line.

\begin{tabular}{|c|c|c|c|c|c|c|}
\hline \multirow{2}{*}{$\begin{array}{l}\text { date, time } \\
\text { 【remarks }\end{array}$} & \multirow{2}{*}{$\begin{array}{l}\text { kind of } \\
\text { insulator }\end{array}$} & \multirow{2}{*}{$\begin{array}{l}\text { meteorological } \\
\text { conditions }\end{array}$} & \multirow{2}{*}{$\begin{array}{c}\begin{array}{c}\text { temperature } \\
\text { distribution of a } \\
\text { string }\end{array} \\
\begin{array}{c}\text { line side } \sim \text { center } \\
\sim \text { earth side }\end{array} \\
\end{array}$} & \multirow{2}{*}{$\begin{array}{l}\text { (reference) surface } \\
\text { temperature of } \\
\text { tower components }\end{array}$} & \multicolumn{2}{|c|}{$\begin{array}{l}\text { Night observation of partial } \\
\text { discharge }\end{array}$} \\
\hline & & & & & visual inspection & $\begin{array}{c}\text { the } \\
\text { darkness } \\
\text { camera }\end{array}$ \\
\hline \multirow{2}{*}{$\begin{array}{c}\text { July.25,2002 } \\
\text { about 3:00 } \\
\text { 【typhoon } \\
\text { No.0209] }\end{array}$} & $\begin{array}{l}\text { High } \\
\text { resistance } \\
\text { glaze }\end{array}$ & \multirow{2}{*}{$\begin{array}{c}25.8^{\circ} \mathrm{C} \\
77 \sim 84 \% \\
1.6 \sim 4.2 \mathrm{~m} / \mathrm{s}\end{array}$} & $23.9 \sim 24.6^{\circ} \mathrm{C}$ & $24.1^{\circ} \mathrm{C}$ & No & Yes \\
\hline & $\begin{array}{c}\text { Ordinary } \\
\text { glaze }\end{array}$ & & $24.9 \sim 28.1^{\circ} \mathrm{C}$ & $25.5^{\circ} \mathrm{C}$ & Yes & Yes \\
\hline \multirow{2}{*}{$\begin{array}{c}\text { October.30 } \\
, 2002 \\
\text { about 3:00 }\end{array}$} & $\begin{array}{l}\text { High } \\
\text { resistance } \\
\text { glaze }\end{array}$ & \multirow{2}{*}{$\begin{array}{c}10.1 \sim 10.4^{\circ} \mathrm{C} \\
47 \sim 52 \% \\
1.0 \sim 2.8 \mathrm{~m} / \mathrm{s}\end{array}$} & $10.1 \sim 10.4^{\circ} \mathrm{C}$ & \multirow{2}{*}{$10.1^{\circ} \mathrm{C}$} & No & No \\
\hline & $\begin{array}{c}\text { Ordinary } \\
\text { glaze }\end{array}$ & & $10.1 \sim 10.7^{\circ} \mathrm{C}$ & & No & No \\
\hline \multirow{2}{*}{$\begin{array}{c}\text { January.31 } \\
2003 \\
\text { about } 4: 00\end{array}$} & $\begin{array}{l}\text { High } \\
\text { resistance } \\
\text { glaze }\end{array}$ & \multirow{2}{*}{$\begin{array}{c}1.5 \sim 1.9^{\circ} \mathrm{C} \\
52 \sim 58 \% \\
0.6 \sim 4.3 \mathrm{~m} / \mathrm{s}\end{array}$} & $-1.1 \sim 3.14^{\circ} \mathrm{C}$ & $\begin{array}{l}-0.57 \sim \\
3.11^{\circ} \mathrm{C} \\
\end{array}$ & No & No \\
\hline & $\begin{array}{c}\text { Ordinary } \\
\text { glaze }\end{array}$ & & $-1.1 \sim 0^{\circ} \mathrm{C}$ & $-0.57^{\circ} \mathrm{C}$ & No & No \\
\hline \multirow{2}{*}{$\begin{array}{c}\text { April.23 } \\
, 2003 \\
\text { about 21:00 }\end{array}$} & $\begin{array}{l}\text { High } \\
\text { resistance } \\
\text { glaze }\end{array}$ & \multirow{2}{*}{$\begin{array}{c}15.8 \sim 16.7^{\circ} \mathrm{C} \\
74 \sim 82 \% \\
0 \sim 0.4 \mathrm{~m} / \mathrm{s}\end{array}$} & $15.0 \sim 19.9^{\circ} \mathrm{C}$ & $14.6^{\circ} \mathrm{C}$ & No & Yes \\
\hline & $\begin{array}{c}\text { Ordinary } \\
\text { glaze }\end{array}$ & & $13.4 \sim 17.0^{\circ} \mathrm{C}$ & $13.2^{\circ} \mathrm{C}$ & Yes & Yes \\
\hline
\end{tabular}

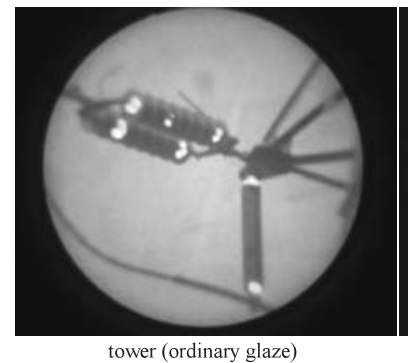

ower (ordinary glaze)

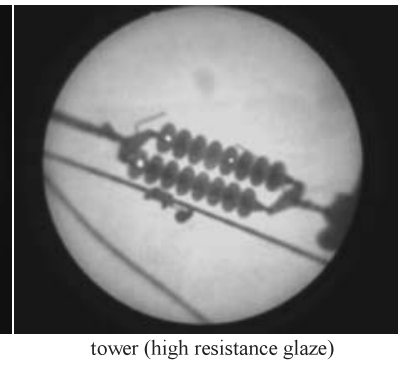

tower (high resistance glaze)
図 19 夜間部分放電観測結果 $(77 \mathrm{kV}$ 送電線)

Fig. 19. Night Observation results of partial discharge on $77 \mathrm{kV}$ transmission line.

分放電音が発生した日の当該箇所の状況を観測するととも に, $275 \mathrm{kV}$ 送電線と同樣, 台風通過後等には夜間にがいし 表面温度観測と部分放電観測を実施した。また，隣接鉄塔 に設置したパイロットがいしの塩分付着密度を定期的に測 定した。

$77 \mathrm{kV}$ 送電線の夜間観測結果を表 7 に示す。表 7 のとお り，観測期間中に特異な発熱は見られなかった。また，平 成 14 年台風 9 号通過後 (7月 25 日観測)，観測鉄塔（高抵 抗導電婇) において，暗視カメラではピン周辺にわずかに 部分放電の発生が確認されたものの，目視では確認できず， 部分放電音もなかった。

これに対し，観測鉄塔（通常釉）においては，暗視カメ ラおよび目視で全相のピン周辺に部分放電の発生および部 分放電音が確認された。これと同樣の状況は, 平成 15 年 4 月 23 日観測においても確認された。この状況を図 19 に 示す。

また，常時污損状態での部分放電音発生有無について観 測期間中 86 日間にわたり耳目により観測した結果を表 8 に，塩分付着量測定結果を表 9 に示す。暴露期間中の樣々

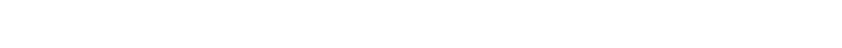
はかすかな部分放電音の発生が 3 日しか確認されなかった 
表 8 部分放電音耳目観測結果 (77 kV 送電線)

Table 8. Inspection results of audible noise on $77 \mathrm{kV}$ transmission line.

\begin{tabular}{|c|l|c|}
\hline \multirow{2}{*}{ item } & \multicolumn{2}{|c|}{ the observation duration } \\
\cline { 2 - 3 } & \multicolumn{1}{|c|}{ Ordinary glaze } & $\begin{array}{c}\text { Semiconducting } \\
\text { glaze }\end{array}$ \\
\hline \hline $\begin{array}{c}\text { the } \\
\text { observation } \\
\text { duration }\end{array}$ & $\begin{array}{l}\text { May.15 October.26/2001:48 days } \\
\text { May.10 September.1717/2002:38 } \\
\text { days }\end{array}$ \\
\hline time zone & \multicolumn{2}{|c|}{ total : 86 days } \\
\hline $\begin{array}{c}\text { audible } \\
\text { noise level }\end{array}$ & $\begin{array}{c}\text { Recorded level A } \\
\text { for 52 days }\end{array}$ & $\begin{array}{c}\text { Recorded slight } \\
\text { noise for 3 days }\end{array}$ \\
\hline
\end{tabular}

※: level of audible noise
A : very Low
$B$ : Low
C : High
D : very High

表 9 塩分付着密度測定結果 (77 kV 送電線)

Table 9. ESDD mesuring on $77 \mathrm{kV}$ transmission line.

\begin{tabular}{|c|c|c|c|c|c|}
\hline \multirow{2}{*}{ item } & \begin{tabular}{c} 
Measure \\
-ment \\
\cline { 3 - 6 }
\end{tabular} & \multicolumn{4}{|c|}{ exposure period by pilot insulator } \\
\cline { 3 - 6 } & $\begin{array}{c}\text { upper } \\
\text { ESDD } \\
\text { surface }\end{array}$ & 0.050 & 0.032 & 0.027 & 0.037 \\
\cline { 2 - 6 }$\left(\mathrm{mg} / \mathrm{cm}^{2}\right)$ & $\begin{array}{c}\text { lower } \\
\text { surface }\end{array}$ & 0.070 & 0.049 & 0.036 & 0.141 \\
\cline { 2 - 6 } & average & 0.058 & 0.042 & 0.033 & 0.101 \\
\hline
\end{tabular}

Note) Maximum ESDD during observation

* : on August 22, 2001 (After typhoon No.0111)

のに対し，観測鉄塔 (通常釉) においては部分放電音の発 生が52 日も確認された。このことから, 通常釉がしに比 ベ, 高抵抗導電釉がいしには部分放電音抑制効果があるこ とが確認できた。なお，観測期間におけるパイロットがい しの最大塩分付着密度は $0.141 \mathrm{mg} / \mathrm{cm}^{2}$ であった。

\section{6. まとめ}

本研究の成果を以下に列記する。

（1）がいしの熱エネルギー収支をもとに，導電釉がい しの熱逸走メカニズムを推定し，各試験により確認・定量 化した。

(2) 高抵抗導電釉がいしの最適な釉薬抵抗值は，熱安 定性, 部分放電音抑制効果, 導電釉の長期劣化および製造 上の釉薬配合や厚さの変動を考慮し，250 M $2 \sim 500 \mathrm{M} \Omega$ と 設定した。

(3) がいし温度を指標として, 海水の飛沫に曝される ような゙污損環境下での導電釉がいしの熱逸走限界をがいし 温度 $130^{\circ} \mathrm{C}$, 許容温度上昇 $+90 \mathrm{~K}$ (設計周囲温度 : $40^{\circ} \mathrm{C}$ ) であることを確認した。

（4）許容温度上昇を上回るのは, 無風状態で実施した 5〜9 個/連の塩水注水試験のみであり，この場合でも風速 $8 \mathrm{~m} / \mathrm{s}$ があれば温度上昇は 20〜 $30 \mathrm{~K}$ 程度に抑えられた。海 水の飛沫に曝される条件下では風速 $10 \mathrm{~m} / \mathrm{s}$ を超えることが
十分期待できるため, 高抵抗導電釉がいしが熱逸走するこ とはないと評価した。

（５）がいし磁器は, 許容温度上昇を大きく上回る冷熱 強度を有していることを確認した。

( 6 ) $275 \mathrm{kV}$ 送電線 (設計 ESDD $1.0 \mathrm{mg} / \mathrm{cm}^{2}$ ) および $77 \mathrm{kV}$ 送電線 (設計 ESDD $0.5 \mathrm{mg} / \mathrm{cm}^{2}$ ) において，2 年間 のフィールド検証試験を実施し，高抵抗導電釉がいしの熱 逸走抑制効果および部分放電音抑制効果ついて実用性能を 確認した。これにより, 海水の飛沫に曝されるような污損 環境下での部分放電音抑制技術として実用化可能であるこ とが明らかとなった。

今後は高抵抗導電釉がいしの不良がいし検出方法に関す る研究を進め, メンテナンス技術の確立を目指す。

最後に, 本研究を推進するに当たり, 多くの方々のこ指 導・こ協力を賜った。ここに深甚なる謝意を表します。 (平成 16 年 2 月 23 日受付, 平成 16 年 6 月 24 日再受付)

$$
\text { 文献 }
$$

(1) Y. Suzuki, Y. Nakashima, S. Mori, S. Ito, and M. Akizuki: "Application Design and Field Results of Semiconducting Glaze Insulators", NGK Rev., No.58, pp.15-28 (1999-12) (in Japanese)

鈴木良博・中島康裕・森 重男・伊藤 進・秋月優宏 :「全面導電釉 がいし適用設計とフィールド実績」, NGK レビュー, No.58, p.15-28 (1999-12)

(2) Y. Suzuki, S. Ito, K. Miyahara, and M. Miyazaki: "Electric Characteristics of High-resistance Semiconducting Glaze Suspension Insulators under Contaminated Conditions", 2001 National Convention Record IEE Japan, No.7-072 (2001) (in Japanese)

鈴木良博・伊藤 進·宮原幸二・宮崎慎一 : 「高抵抗全面導電釉懸垂 がいしの污損性能」, 平 13 電気学会全国大会, No.7-072 (2001)

(3) 電気学会 : 「架空送電線の電流容量」, 電気学会技術報告, No.660, pp.8 (1997-8)

（4）村田八束：「冷熱試験について」, 日碍レビュー, No.24 (1961-5)

篠 田 明秀 (正員) 1956 年 4 月 13 日生。1979 年 3 月東京

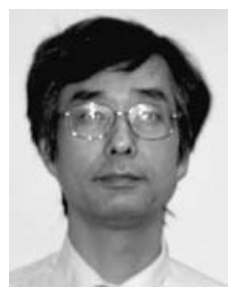
大学工学部電気工学科卒業。同年 4 月中部電力 (株) 入社。現在工務部技術開発グループに勤務。 主として送変電設備に関する研究開発に従事。

知屋城 清 信 (正員) 1953 年 11 月 28 日生。1977 年 3 月同志

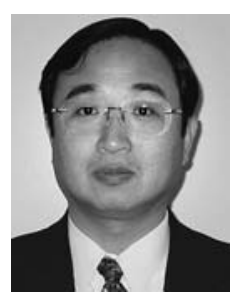
社大学工学部電気工学科卒業。同年 4 月中部電力 (株) 入社。現在研究企画部企画グループに勤務。 主として研究開発・計画策定業務に従事。 
岡田英幸 (正員) 1964 年 10 月 3 日生。1 987 年 3 月慶応

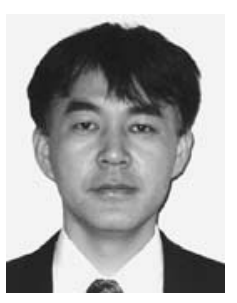
義塾大学理工学部電気工学科卒業。同年 4 月中 部電力 (株) 入社。現在工務部技術開発グループ に勤務。主として送変電設備に関する研究開発に 従事。

鈴木良博 (正員) 1950 年 12 月 10 日生。1973 年 3 月名 古屋大学卒業。同年 4 月日本ガイシ (株) 入社。 主として高電圧がいしの設計および污損特性 , イ ンパルス電圧特性等の高電圧試験研究に従事。現 在 , 同社ガイシ技術部長。工学博士。IEEE およ びCIGRE 会員。

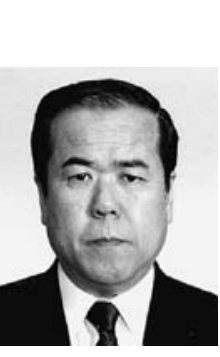

進 (正員) 1948 年 9 月 21 日生。1969 年 3 月鈴鹿工 業高等専門学校卒業。同年 4 月日本ガイシ (株) 入社。現在, 同社電力技術研究所勤務。主として がいしの高電圧研究, 污損耐電圧特性の研究に従 事。IEEE 会員。

内 藤 克 彦 (終身会員) 1934 年 12 月 24 日生。1960 年 3 月

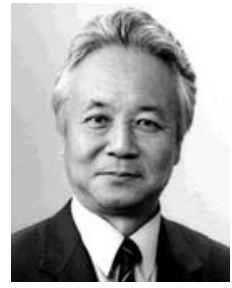
名古屋大学大学院修士課程終了。同年日本ガイシ (株) 入社。1991 年同社退社後, 名古屋工業大学教 授。9 8 年同大学退官後, 名城大学電気電子工学科 教授。高電圧, 絶縁, 電磁界等の研究に従事。工学 博士。IEEE Life Fellow。IEEE DLP Distinguished Lecturer。CIGRE 特別会員。 